\begin{tabular}{lc}
\hline \hline UAD & Jurnal Psikologi Terapan dan Pendidikan \\
Vol. 2, No. 1, Mei 2020, ph. 21-30 \\
ISSN $2715-2456$
\end{tabular}

\title{
Regulasi diri pada remaja putri yang pernah mengalami eksploitasi
}

\author{
Trifani Mayka Ratria,1, Sri Kushartatib,2* \\ a,bFakultas Psikologi, Universitas Ahmad Dahlan, Yogyakarta \\ 1trifanimayka@gmail.com; *2sri.kushartati@psy.uad.ac.id \\ *Correspondent Author
}

\section{KATAKUNCI}

eksploitasi seksual; regulasi diri; remaja putri

\section{KEYWORDS}

female adolescent; self-regulation; sexual exploitation

\section{ABSTRAK}

Beberapa tahun terakhir ini, Indonesia mengalami kondisi yang memprihatinkan terkait dengan tingginya kasus kekerasan seksual. Agar para korban yang telah mengalami dampak dari kekerasan seksual tidak menjadi buruk, maka diperlukan adanya regulasi diri yang tepat. Penelitian ini bertujuan untuk mengetahui regulasi diri yang dimiliki oleh remaja putri yang pernah mengalami eksploitasi seksual, faktor yang mempengaruhi regulasi diri, serta dampak yang dialami setelah eksploitasi seksual. Metode penelitian yang digunakan adalah kualitatif dengan pendekatan studi kasus. Subjek dalam penelitian ini adalah seorang remaja putri yang pernah mengalami eksploitasi seksual. Metode pengambilan data pada penelitian ini menggunakan wawancara, observasi, dan studi dokumen. Data hasil penelitian dianalisis menggunakan content analysis. Sementara untuk memenuhi syarat kredibilitas data, peneliti menggunakan metode triangulasi, yaitu triangulasi sumber dan triangulasi metode. Hasil penelitian menunjukkan bahwa subjek telah mampu melakukan regulasi diri dengan cukup baik. Regulasi diri dilakukan dengan cara menolak setiap pemberian yang merupakan imbalan kencan, menjual hp dan mengganti nomor, serta menghindar dan menolak untuk ditemui atau diajak kencan. Penelitian ini menyimpulkan bahwa faktor internal regulasi diri subjek terdiri dari dua hal, motivasi dari dalam diri dan kepribadian yang mudah menerima masukan dari orang lain. Motivasi muncul karena adanya penolakan atas perlakuan yang subjek terima, serta adanya observasi diri dan proses penilaian yang subjek lakukan terhadap dirinya sendiri. Faktor eksternal regulasi diri subjek yaitu terdiri dari dukungan sosial dalam bentuk emotional atau esteem support, informational support, dan companionship support dari orang-orang di sekelilingnya. Akibat eksploitasi seksual yang terjadi pada dirinya, subjek mengalami dampak secara fisik dan psikologis.

\section{Self-regulation in young women who have experienced exploitation}

In the last few years, Indonesia has experienced poor conditions related to the high number of sexual violence cases. In order for victims who have experienced the effects of sexual violence not to become bad, proper self-regulation is needed. This study aims to explore selfregulation owned by a female adolescent who experienced sexual exploitation, the factors that affect her self-regulation, and the impact experienced after sexual exploitation. The research method used in this research was qualitative with a case study approach. Subject in this study was a female adolescent who had experienced sexual exploitation. 
Data collection methods in this study used interviews, observation, and document studies. Research data were analyzed using content analysis. To meet the data trustworthiness requirements, researchers used the methods of triangulation, those were source triangulation and method triangulation. The results showed that the subject was able to selfregulate quite well. Self-regulation was done by refusing any gift that was in return for having a date, selling her cellphone and changing her number, as well as avoiding and refusing to meet or having to date. This study concluded that the internal factors of subject self-regulation consisted of two things, internal motivation and a personality that easily accepted input from others. Motivation emerged due to refusal of treatment the subject received, as well as her self-observation and assessment processes done by herself. The external factor of the subject's self-regulation was the existence of social support in the form of emotional or esteem support, informational support, and companionship support from people around her. As a result of sexual exploitation that occurs in her, the subject experienced physical and psychological impact.

This is an open-access article under the CC-BY-SA license.

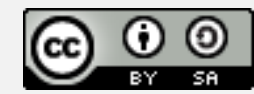

\section{Pendahuluan}

Aktivitas seksual, di mana orang dewasa atau anak lain yang usianya lebih tua atau orang lain yang memiliki pengetahuan lebih, memanfaatkannya untuk kesenangan seksual atau aktivitas seksual (Maslihah, 2013). Menurut Lyness (dalam Maslihah, 2013) kekerasan seksual dapat berupa tindakan menyentuh atau mencium organ seksual anak, pemerkosaan, memperlihatkan media atau benda porno, dan menunjukkan alat kelamin pada anak. Adapun bentuk kekerasan seksual pada anak yang kini marak terjadi adalah eksploitasi seksual, yang justru dilakukan oleh orang terdekat anak karena dilatarbelakangi faktor ekonomi.

Komisi Nasional Perlindungan Anak (komnas PA) menyebut pengaduan pelanggaran hak anak terus meningkat, berdasar Pusat Data dan Informasi Komnas Anak, dalam kurun waktu 2010-2015, yang sebagian besar didominasi oleh kasus kejahatan seksual. Seperti yang di lansir liputan6.com tanggal 22 Desember 2015 (Putra, 2015), jumlah kasus dalam kurun waktu tersebut terus mengalami peningkatan. Begitupula Kabupaten Kulon Progo, Propinsi DIY juga tidak luput dari keadaan darurat kasus kekerasan pada anak. Berdasarkan catatan kasus kekerasan terhadap perempuan dan anak di Badan Pemberdayaan Perempuan dan Masyarakat DIY (BPPM DIY, 2014), diketahui bahwa di Kulon Progo anak pada tingkat SLTP merupakan kelompok yang paling rentan mengalami tindak kekerasan, khususnya kekerasan seksual. Anak pada tingkat SLTP berada pada rentang usia 12 hingga 15 tahun, kelompok usia ini disebut dengan masa remaja awal (Hutabarat, dkk., 2010).

Menurut Erikson (dalam Santrock, 2007), pada masa ini remaja dihadapkan pada tantangan untuk menemukan dirinya, tentang siapa dirinya, dan bagaimana kehidupannya mendatang ketika dewasa. Tugas perkembangan tersebut membuat remaja memiliki rasa ingin tahu yang besar, sehingga remaja senang mencoba hal-hal baru. Berawal dari rasa ingin tahu dan coba-coba tersebut remaja kemudian melakukan banyak perubahan perilaku dari yang sudah ada sejak masa anak-anak menjadi disesuaikan dengan gambaran idealnya pada saat itu. Bandura (dalam Alwisol, 2012), tingkah laku manusia dapat terjadi akibat adanya timbal balik yang terus menerus antara kognitif, perilaku, dan lingkungan. Melalui interaksi timbal balik tersebut maka orang akan dapat menentukan atau mengontrol tingkah lakunya 
dengan mengontrol kekuatan lingkungan, tetapi orang tersebut juga dikontrol oleh kekuatan lingkungan. Kemampuan seseorang untuk mengontrol tingkah lakunya sendiri itu disebut regulasi diri.

Bandura (dalam Alwisol, 2012) menyebutkan bahwa manusia sebagai pribadi memiliki kemampuan untuk dapat mengatur diri sendiri (meregulasi diri). Kemampuan tersebut penting untuk dimiliki agar seseorang dapat mengembangkan dirinya untuk mencapai keadaan yang diinginkan, serta mampu menghadapi berbagai peristiwa yang terjadi, baik yang menyenangkan maupun yang tidak menyenangkan. Agar remaja dapat melaksanakan tugas perkembangan dengan baik dan tidak terjerumus pada lingkungan yang salah, maka regulasi diri menjadi hal yang perlu para remaja miliki. Ketika seseorang dapat mengontrol dirinya, maka orang tersebut akan dapat mengendalikan atau mengatur perilakunya untuk mencapai keadaan akhir atau tujuannya (McCullough \& Willoughby, 2009). Seperti halnya remaja yang mencoba-coba berbagai hal baru demi memuaskan rasa keingintahuannya dan dapat mencapai keadaan sesuai diri ideal yang remaja inginkan.

Memiliki regulasi diri yang baik merupakan hal yang cukup sulit bagi remaja dengan beberapa kondisi tertentu, misalnya berada di lingkungan tempat tinggal yang kurang mendukung atau pernah mengalami kejadian traumatis seperti eksploitasi seksual. Kedua kondisi tersebut sudah tentu menimbulkan kesulitan yang cukup besar bagi remaja untuk dapat melakukan tugas perkembangan dengan baik, begitupula memiliki regulasi diri yang baik. Pengalaman yang traumatis menjadi korban eksploitasi seksual ditambah dengan berbagai dampak buruk yang dialami remaja tentu saja sangat mempengaruhi segala aspek diri remaja tersebut seperti aspek kognitif, afektf, ataupun perilaku yang merupakan unsur penting dalam melakukan regulasi diri.

Terdapat berbagai dampak buruk yang dapat mengancam para korban kekerasan seksual. Dampak tersebut dapat terjadi dalam berbagai bentuk yang berbeda-beda pada tiap orang, seperti secara fisik, sosial, dan psikologis. Menurut Sisca dan Moningka (2008), kekerasan seksual tersebut dapat memberikan dampak traumatis hingga sangat mengkhawatirkan karena dapat menimbulkan dampak jangka panjang selama hidup anak. Agar para korban yang telah mengalami dampak dari kekerasan seksual tersebut tidak menjadi semakin terpuruk hingga akhirnya terjebak pada pergaulan bebas, maka diperlukan adanya regulasi diri yang tepat. Dampak apa saja yang akan dialami korban setelah mengalami eksploitasi seksual juga sangat tergantung dengan regulasi dirinya.

Menurut Dariyo (2011), regulasi diri merupakan kemampuan untuk mengelola, mengontrol, dan mengarahkan semua potensi, sikap, pemikiran maupun perilakunya untuk pengembangan diri sendiri. Menurut Miller dan Brown (dalam Neal \& Carey, 2005), terdapat tujuh tahap dalam proses regulasi diri. Ketujuh tahap tersebut yaitu, informational input, selfevaluation, instigation to change triggered by perceptions of discrepancy, search for ways to reduce discrepancy, planning for change, implementation of behavior change, dan evaluation of progress towards a goal.

Regulasi diri terjadi dengan dipengaruhi oleh dua faktor, yaitu faktor internal dan eksternal. Faktor internal dalam regulasi diri yaitu observasi diri, proses penilaian, dan reaksi diri (Bandura, 1991) Faktor eksternal yaitu faktor yang muncul dari luar diri individu yang akan mempengaruhi regulasi diri dengan dua cara. Pertama, faktor eksternal akan memberi standar evaluasi tingkah laku melalui interaksi antara faktor lingkungan dengan pengaruhpengaruh pribadi. Kedua, faktor eksternal akan menyediakan cara untuk mendapatkan penguatan (reinforcement) (Feist \& Feist, 2010). Kedua faktor itu akan saling berinteraksi dan mempengaruhi regulasi diri seseorang.

Eksploitasi seksual merupakan salah satu bentuk kekerasan seksual yang dilakukan oleh orang dewasa dan ada unsur komersialisasi melalui pemberian sejumlah imbalan. Bentukbentuk eksploitasi seksual yaitu pelacuran, pornografi, perdagangan, wisata seks, dan perkawinan anak, di mana dalam masing-masing bentuk tersebut anak dijadikan sebagai 
objek seksual dan objek komersial (Sofian \& Ramlan, 2008). Akibat eksploitasi seksual, seseorang dapat terancam beberapa dampak. Secara fisik, antara lain kerusakan organ tubuh, kemungkinan terinfeksi penyakit menular seksual (PMS), kehamilan yang tidak dikehendaki (Sulistyaningsih \& Faturochman, 2002), dan insomnia (Maslihah, 2013). Secara sosial, dampak yang rentan dialami adalah penggunaan narkoba, perilaku agresif (Hidayah, 2007), takut pada berbagai penyalahgunaan, keinginan bunuh diri, dan potensi menjadi pelaku kekerasan yang sama di kemudian hari (Maslihah, 2013). Dampak selanjutnya yaitu dampak psikologis, seperti gangguan panic, skizofrenia (Hidayah, 2007), somatisasi, PTSD, depresi, dan gangguan kepribadian (Sulistyaningsih \& Faturochman, 2002; Hidayah, 2007; Maslihah, 2013).

Berdasarkan uraian di atas, maka peneliti tertarik untuk mengangkat isu tersebut untuk mengetahui regulasi diri, faktor-faktor yang mempengaruhinya, serta dampak yang dialami remaja putri yang pernah mengalami eksploitasi seksual. Adapun kontribusi penelitian ini adalah mampu memberikan pengetahuan khsuusnya pada bidang psikologi sosial, serta pemahaman yang lebih terkait dengan konsep regulasi diri berdasarkan penelitian empiris di lapangan.

\section{Metode}

Penelitian ini merupakan penelitian kualitatif, yaitu penelitian untuk memahami sesuatu hal, menggunakan tradisi metodologi penyelidikan yang mengeksplorasi problem manusia atau problem sosial (Creswell, 1998). Pendekatan yang digunakan dalam penelitian ini adalah pendekatan studi kasus. Menurut Azwar (2010), studi kasus merupakan suatu penyelidikan mendalam (indepth study) mengenai suatu unit sosial sedemikian sehingga menghasilkan gambaran yang terorganisasikan dengan baik dan lengkap mengenai unit sosial tersebut. Tujuan dilakukannya studi kasus diantaranya adalah mempelajari secara intensif latar belakang, status terakhir, dan interaksi lingkungan yang terjadi pada suatu satuan sosial tertentu (Azwar, 2010). Studi kasus dapat membuat peneliti memiliki pemahaman yang utuh dan terintegrasi mengenai fakta-fakta dan dimensi dari kasus yang menjadi bahan penelitian (Poerwandari, 2007). Adapun karakteristik dari subjek penelitian ini adalah seorang remaja putri yang pernah mengalami ekploitasi seksual. Subjek penelitian ini didapatkan dari Lembaga $\mathrm{X}$ yang menangani korban kekerasan terhadap perempuan dan anak, subjek adalah salah satu korban yang didampingi oleh Lembaga tersebut.

Metode pengambilan data dalam penelitian ini yaitu wawancara, observasi non partisipan, dan studi dokumen. Penelitian ini menggunakan wawancara yang menggunakan panduan wawancara. Patton (dalam Poerwandari, 2007), menyebutkan bahwa dalam proses wawancara dengan menggunakan panduan umum wawancara ini, wawancara dilengkapi dengan panduan yang umum, serta mencantumkan isu-isu yang harus diliput dengan tidak terpaku pada urutan pertanyaan yang kaku, seringkali pertanyaan disampaikan secara implisit. Metode observasi yang digunakan adalah observasi non partisipan, yaitu observer tidak tidak terlibat dalam kehidupan orang yang diamati (Hadi, 2004). Studi dokumen juga dilakukan karena dalam pendekatan studi kasus diperlukan adanya kelengkapan informasi dari subjek penelitian (Prastowo, 2011).

Data hasil penelitian dianalisis menggunakan content analysis yang merupakan analisis ilmiah tentang isi pesan pada suatu komunikasi (Muhadjir, 2007). Sementara untuk memenuhi syarat kredibilitas data penelitian, peneliti melakukan triangulasi, yaitu triangulasi sumber data dan triangulasi metode. Peneliti menggunakan wawancara kepada significant person, yaitu orang lain yang mengetahui informasi tentang subjek sebagai langkah dalam triangulasi sumber. Triangulasi yang kedua adalah triangulasi metode, yaitu pengecekan derajat keterpercayaan hasil temuan dengan menggunakan lebih dari satu cara pengumpulan data penelitian (Moleong, 2010). 


\section{Hasil dan Pembahasan}

Peneliti melakukan pengambilan data penelitian menggunakan metode wawancara kepada subjek dan dua orang significant person, observasi yang dilakukan pada saat wawancara, serta studi dokumen berupa laporan hasil pendampingan dari konselor. Penelitian tersebut menghasilkan beberapa temuan di lapangan yang kemudian diolah sehingga dapat tersaji dalam bentuk hasil observasi serta gabungan antara hasil wawancara dan studi dokumen.

Subjek (inisial SPR) adalah seorang perempuan yang berusia 19 tahun, dan mempunyai pekerjaan sebagai pengasuh balita. Secara umum tampilan fisik subjek sesuai dengan penampilan remaja seusianya, namun tampak kurang dapat merawat diri yang ditunjukkan dengan pakaian yang tampak kotor, rambut panjang sebahu berwarna hitam kecoklatan yang dipenuhi dengan telur kutu berwarna putih. Subjek orang yang ramah dan sopan, dan mampu berkomunikasi dengan lancar dan spontan. Subjek menggunakan Bahasa Indonesia dan diselingi dengan Bahasa Jawa pada saat dilakukan wawancara. Pada saat dilakukan wawancara, subjek tidak dapat secara pasti menyebutkan tanggal lahirnya, hanya dapat menyebutkan bahwa usianya 19 tahun.

Sebagai remaja yang berada dalam situasi yang negatif serta tingkat kognitif yang rendah, subjek telah mampu melakukan proses regulasi diri. Seperti yang disebutkan oleh Dariyo (2010), regulasi diri ini merupakan usaha untuk dapat melakukan pengembangan diri dan mencapai tujuan yang diharapkan. Bagi subjek yang berada dalam situasi eksploitasi seksual, tujuan yang diharapkannya adalah dapat keluar dari situasi tersebut, terhindar dari orang-orang yang terlibat di dalamnya, serta dapat memperoleh kehidupan yang lebih baik dari keadaannya saat itu. Oleh karena itu, untuk dapat mencapai tujuannya maka subjek harus melakukan regulasi diri dengan cara mengelola, mengontrol, dan mengarahkan semua potensi, sikap, pemikiran, dan perilakunya (Dariyo, 2010).

Sejak pertama kali dipaksa melayani laki-laki, subjek telah dapat melakukan regulasi diri yang dilatarbelakangi ketidaknyamanannya terhadap perlakuan yang ia terima. Regulasi diri dilakukan subjek dengan melakukan perlawanan, akan tetapi tenaganya yang tidak sebanding akhirnya memaksa subjek untuk menyerah dan pasrah kepada laki-laki yang saat itu mengencaninya. Kondisi tersebut mengakibatkan subjek hanya dapat melakukan regulasi diri sampai pada tahap ketiga, yaitu muncul dorongan dari dalam diri untuk melakukan perubahan karena ketidaksesuaian antara kondisi dengan yang diharapkannya (Neal \& Carey, 2005).

Pada kesempatan selanjutnya ketika subjek kembali dipaksa melayani laki-laki, subjek bermaksud kembali melakukan usaha penolakan karena pengalaman sebelumnya yang dianggap tidak menyenangkan. Namun, dalam proses regulasi diri sebagai usaha penolakan kali ini subjek tidak dapat memperlihatkan tahap keempat dan kelima yaitu mencari solusi serta merancang rencana perubahan. Pada saat itu subjek langsung pada tahap keenam yaitu menerapkan cara yang dipilihnya (Neal \& Carey, 2005). Perilaku yang dipilih subjek pada saat itu ialah menolak segala bentuk imbalan yang diberikan kepadanya.

Menjadi korban eksploitasi seksual membawa subjek pada kondisi psikologis yang buruk, di mana subjek pada akhirnya mengalami depresi. Namun, dengan keadaannya tersebut, subjek justru menjadi mendapatkan perhatian dan dukungan dari berbagai pihak yang peduli terhadapnya. Permasalahan subjek dilaporkan pada lembaga yang menangani permasalahan seputar perlindungan perempuan dan anak di Kabupaten Kulon Progo, sehingga subjek segera mendapat penanganan yang tepat. Melalui serangkaian pemeriksaan yang dijalani, subjek diberi informasi mengenai kondisinya saat itu, baik kondisi yang terkait dengan kesehatan maupun psikologisnya. Beragam nasehat dan informasipun diterima subjek, terutama pesan agar subjek berani memutuskan untuk tidak akan mau jika diajak berkencan lagi. Subjek menerima seluruh informasi itu dengan mudah dan tanpa ada penolakan, karena subjek merupakan seorang individu yang penurut. 
Proses evaluasipun terjadi di dalam diri subjek, berdasarkan pada informasi-informasi yang telah subjek terima sebelumnya (Neal \& Carey, 2005). Informasi-informasi tersebut memahamkan subjek bahwa dirinya telah mendapatkan perlakuan yang tidak manusiawi dan telah dijadikan objek perdagangan. Sejak saat itu, munculah dorongan dari dalam diri subjek untuk melakukan perubahan pada keadaannya (Neal \& Carey, 2005). Dorongan tersebut tumbuh begitu kuat dan memotivasinya untuk menghindar dari orang-orang yang berniat buruk kepadanya. Harapan subjek sangat besar agar jangan ada orang yang mencari-carinya lagi, sehingga subjek pun menghindar dan menghalangi orang dapat menghubunginya sebagai solusi dari permasalahannya. Setelah memilih solusi tersebut, subjek pun menyusun rencana pelaksanaannya (Neal \& Carey, 2005). Subjek memilih cara yang dianggapnya tepat, yaitu dengan menjual hp dan mengganti nomornya karena di dalamnya tersimpan nomor telepon orang-orang yang ingin subjek hindari.

Rencana yang telah disusun selanjutnya diterapkan oleh subjek (Neal \& Carey, 2005). Subjek menjual hpnya dan tak lupa mengganti nomornya. Semenjak itu, tidak ada lagi yang menghubungi atau mencarinya. Langkah yang dilakukan subjek pada kenyataannya membawa perubahan yang positif pada kehidupannya saat itu. Subjek menilai cara yang telah dilakukannya tersebut berhasil mewujudkan harapannya untuk terhindar dari orang-orang yang memperdayainya. Subjekpun dapat berhasil keluar dari eksploitasi seksual yang menimpanya. Keberhasilan tersebut membawa perubahan yang baik pada kehidupan subjek sehari-hari. Salah satu buktinya yaitu pada saat ini subjek telah memiliki aktivitas sehari-hari yang bermanfaat bagi dirinya. Adapun aktivitas tersebut yaitu mengasuh anak tetangga di dekat rumahnya. Aktivitas tersebut dapat melatih kemampuan sosialisasi subjek yang sempat terganggu setelah mengalami depresi. Selain itu, pekerjaan tersebut juga dapat memberikan penghasilan yang halal bagi subjek.

Regulasi diri SPR tidak terjadi begitu saja, melainkan ada faktor-faktor yang mempengaruhi. Faktor tersebut terdiri dari faktor eksternal dan faktor internal. Faktor eksternal merupakan faktor yang datang dari luar diri individu yang turut berkontribusi terhadap proses regulasi diri individu tersebut (Feist \& Feist, 2010). Pada regulasi diri subjek, faktor eksternal tersebut ada dalam bentuk dukungan sosial dari berbagai pihak. Menurut Uchino (Sarafino \& Smith, 2012), dukungan sosial merupakan suatu bentuk kenyamanan, kepedulian, penghargaan, atau bantuan yang tersedia bagi seseorang untuk orang atau kelompok lainnya. Terdapat empat bentuk dukungan sosial, yaitu emotional or esteem support, tangible or instrumental support, informational support, dan companionship support (Sarafino \& Smith, 2012). Tiga di antara empat bentuk dukungan sosial tersebut didapatkan subjek dari orang-orang di sekitarnya, seperti emotional or esteem support, informational support, dan companionship support.

Sesuai dengan yang disampaikan Sarafino dan Smith (2012), bahwa dukungan secara emosi dapat diberikan dalam bentuk empati, kepedulian, perhatian, dan penghargaan positif kepada seseorang. Ibu subjek yang menjadi satu-satunya keluarga terdekat subjek pada saat itu memberikan dukungan emosional dengan kasih sayang yang diberikannya. Subjek selalu diberi perhatian penuh oleh ibunya, di mana subjek selalu dirawat dan disediakan segala kebutuhannya. Dukungan emosional lainnya datang dari lingkungan sekitar subjek, yaitu Ibu Dukuh dan para tetangganya. Ibu dukuh memberikan perhatian dan menyayangi subjek seperti anaknya sendiri, serta membantu melengkapi apa yang menjadi keterbatasan ibu kandung subjek dalam menyelesaikan permasalahan subjek. Para tetangga di sekitar rumah subjek seringkali datang berkunjung dan menanyakan perkembangannya saat itu. Para tetangga tidak pernah mencemooh atas apa yang subjek alami karena mereka memahami bahwa subjek merupakan korban, maka para tetangga pun turut memberikan dukungan kepada subjek agar dapat segera pulih.

Dukungan sosial yang kedua yaitu dukungan informasi (informational support). Dukungan informasi dapat berbentuk pemberian nasehat, pengarahan, saran, motivasi, atau 
feedback tentang perilaku seseorang (Sarafino \& Smith, 2012). Selama subjek diberikan pendampingan dan menjalani sejumlah pemeriksaan, subjek selalu diberi berbagai informasi mengenai kondisi kesehatannya, resiko yang dihadapi akibat seks bebas, serta hal-hal yang harus dilakukan agar dapat segera sembuh. Berdasarkan informasi-informasi tersebut selanjutnya para pendamping memotivasi subjek agar tidak putus asa dan menyerah pada keadaan.

Dukungan sosial yang ketiga companionship support, yaitu dukungan yang diberikan melalui keberadaan orang lain untuk menghabiskan waktu bersama orang tersebut, sehingga akan memberikan perasaan kebersamaan (Sarafino \& Smith, 2012). Subjek mendapatkan dukungan ini dalam bentuk pendampingan oleh Ibu Dukuh serta petugas dan konselor lembaga X. Ibu Dukuh dan pendamping selalu memantau setiap perkembangan kondisi subjek. Pendamping akan memantau perkembangan subjek secara umum berdasarkan laporan dari Ibu Dukuh. Selanjutnya, pendamping yang akan mengakomodir kebutuhan subjek, seperti mengantarkan subjek periksa ke puskesmas maupun rumah sakit sesuai waktu yang telah ditentukan petugas medis, juga menindaklanjuti setiap keluhan yang muncul dari subjek. Peran kedua belah pihak ini sebagian besar dilakukan juga sebagai upaya menggantikan sebagian peran ibu subjek yang memiliki keterbatasan karena tingkat kognitif dan ekonomi yang rendah.

Beragam dukungan sosial yang didapatkan ini membawa pengaruh yang besar pada proses regulasi diri subjek. Dukungan sosial sebagai faktor eksternal memberikan standar internal pada diri subjek. Subjek akan menilai dan mengevaluasi apa yang ada pada dirinya sesuai dengan standar yang muncul pada dirinya itu. Selain itu, dukungan sosial ini juga menjadi sumber penguatan ekstrinsik bagi subjek untuk dapat melakukan regulasi diri dengan baik. Hal itu karena penguatan intrinsik saja tidaklah cukup bagi subjek untuk mempertahankan perilaku dalam regulasi dirinya.

Faktor internal merupakan faktor yang muncul dari dalam diri subjek itu sendiri. Faktor ini akan berinteraksi dengan faktor eksternal dalam pembentukan regulasi diri (Alwisol, 2012). Berdasarkan hasil temuan penelitian, diketahui bahwa faktor internal yang mempengaruhi regulasi diri subjek yaitu adanya motivasi yang kuat dari dalam dirinya sendiri dan kepribadian subjek yang mudah menerima masukan dari orang lain. Terdapat dua hal yang memotivasi subjek hingga dapat melakukan regulasi diri tersebut. Pertama, penolakan subjek atas perlakuan yang diterima selama mengalami eksploitasi seksual. Penolakan muncul setelah subjek menyadari bahwa dirinya sedang berada pada situasi yang membahayakan dirinya, yaitu akan diperkosa seorang laki-laki dan subjek dijual kepada lakilaki tersebut. Penolakan itu pun yang kemudian subjek munculkan dalam bentuk penolakan setiap imbalan yang diberikan kepadanya, subjek pun selalu berusaha menghindar saat dicari-cari untuk diajak berkencan. Hal kedua yaitu observasi diri dan proses penilaian yang dilakukan subjek terhadap dirinya sendiri. Subjek melihat pada dampak yang terjadi akibat eksploitasi seksual yang dialaminya. Subjek merasakan tubuhnya semakin kurus dan fisiknya terasa kurang sehat, sehingga subjek khawatir akan terkena penyakit menular seksual. Subjek pun membandingkan keadaan dirinya itu dengan temannya, yaitu $\mathrm{W}$ yang juga merupakan seorang gadis korban eksploitasi seksual, akan tetapi pada akhirnya W menjadikan hal tersebut sebagai profesinya hingga saat ini. Mengetahui keadaan W, subjek akhirnya menjadi takut akan bernasib sama seperti $W$, sehingga subjek semakin membulatkan tekadnya untuk dapat berhenti dari seks bebas tersebut.

Faktor internal kedua yang ada pada subjek yaitu kepribadiannya yang mudah menerima masukan dari orang lain. Bandura (dalam Awisol, 2012) menjelaskan bahwa tingkah laku manusia, termasuk regulasi diri, terjadi akibat adanya interaksi timbal balik antara kognitif, perilaku, dan lingkungan. Di dalam interaksi tersebut, peran kognitif seseorang sangat penting agar dapat mengontrol tingkah lakunya dengan mengontrol lingkungan, sehingga orang tersebut tidak akan selalu dikontrol oleh lingkungan. Jika melihat 
pada diri subjek yang memiliki tingkat kognitif yang rendah, maka sulit bagi subjek untuk dapat melakukan regulasi diri secara tepat dalam situasi yang dihadapinya. Namun, subjek berhasil melakukan proses regulasi diri secara sempurna pada ketujuh tahapan yang ada. Regulasi diri itu bahkan telah membawa perubahan keadaan subjek menjadi lebih positif, misalnya dengan pekerjaannya yang baru saat ini. Terjadinya regulasi diri yang baik tersebut karena pengaruh kepribadian subjek yang mudah menerima masukan dari orang lain terutama dari orang yang dihormatinya. Orang-orang tersebut memberikan informasi secara konkrit kepada subjek tentang hal-hal yang harus dihindari atau dilakukan olehnya. Informasi-informasi tersebut disampaikan kepada subjek secara langsung dan menggunakan bahasa yang sederhana, sehingga subjek dapat memahami dan melakukannya secara tepat. Adanya kepribadian yang mudah menerima informasi itu membuat subjek dapat dengan mudah mengikuti saran dan nasehat dari berbagai pihak yang mendampingi, sehingga subjek pun dapat melakukan regulasi diri dengan baik dan keluar dari situasi eksploitasi seksual seutuhnya, meskipun subjek memiliki keterbatasan pada kognitifnya.

Eksploitasi seksual merupakan salah satu bentuk dari kekerasan seksual yang dapat mengakibatkan berbagai dampak buruk bagi korbannya. Setiap korban dapat mengalami dampak yang berbeda serta derajat keparahan yang berbeda pula. Subjek sebagai korban eksploitasi seksual tidak luput dari dampak secara fisik dan psikologis. Secara fisik, subjek mengalami penurunan berat badan secara terus menerus, bagian kemaluannya terasa perih, perut mual-mual, organ seksual terpapar bakteri dan mengalami keputihan. Hal itu sesuai dengan hasil penelitian dari lembaga Rifka Annisa (dalam Hidayat, dkk., 2009) kepada para perempuan korban kekerasan yang didampingi lembaga tersebut. Penelitian itu mengungkapkan sejumlah gangguan dan keluhan pada organ reproduksi sebagai akibat kekerasan terhadap perempuan, yaitu: luka dan nyeri pada alat kelamin, pendarahan, haid tidak teratur, keguguran, infeksi, keputihan, kerusakan pada organ reproduksi, kehamilan tidak diinginkan, dan penularan IMS (Hidayat dkk., 2009).

Dampak lain yang juga dialami SPR adalah dampak secara psikologis. Pertama, subjek mengalami kecemasan dalam bentuk rasa takut yang besar seolah-olah ada orang yang mengejar dan mencari-carinya. Kedua yaitu subjek mengalami trauma yang ditunjukkan dengan perilaku berteriak histeris, berlari, dan bersembunyi saat bertemu dengan laki-laki. Ketiga yaitu disfungsi sosial yang ditunjukkan dengan adanya kesulitan berkomunikasi dengan orang lain, mengurung diri dan menolak melakukan aktivitas apapun selain berdiam diri di dalam kamar selama kurun waktu sebulan, serta hambatan untuk bersosialisasi dengan warga sekitarnya. Keempat, subjek mengalami depresi. Hal yang dialami subjek tersebut sejalan dengan hasil temuan dari penelitian terdahulu, bahwa di antara dampak psikologis yang dapat terjadi pada korban kekerasan seksual adalah kecemasan dan depresi sesuai dengan yang disampaikan oleh Maslihah (2013); Illenia dan Handadari (2011).

\section{Simpulan}

Berdasarkan hasil penelitian dan pembahasan yang telah dilakukan, maka dapat ditarik beberapa kesimpulan dalam penelitian ini, 1) Subjek telah mampu melakukan regulasi diri dengan cukup baik saat berada pada situasi eksploitasi. Regulasi diri tersebut dilakukan dengan tujuan dapat keluar dari situasi tersebut, terhindar dari orang-orang yang terlibat di dalamnya, serta dapat memperoleh kehidupan yang lebih baik dari keadaannya sebelumnya. Proses regulasi diri yang dilakukan subjek yaitu, pertama, subjek menolak setiap pemberian yang diberikan kepadanya sebagai imbalan atas kencan yang sudah dilakukannya. 2) Subjek menjual hp dan mengganti nomornya. 3) Subjek pun selalu berusaha menghindar dari orang yang menjualnya, maupun orang yang mengajaknya berkencan dengan cara menolak ditemui atau diajak berkencan. Cara-cara tersebut pun berhasil membuat subjek mencapai tujuan yang diharapkannya. Keberhasilannya pun membawa perubahan positif, salah satunya yaitu subjek dapat memiliki kegiatan dan pekerjaan baru sebagai pengasuh anak. Regulasi diri 
pada subjek tidak terjadi begitu saja, melainkan dipengaruhi oleh faktor eksternal dan faktor internal. Faktor eksternal datang dari lingkungan sekitar subjek seperti ibu, tokoh masyarakat, pendamping, petugas medis, dan tetangga. Faktor tersebut muncul dalam tiga bentuk dukungan sosial, yaitu emotional or esteem support, informational support, dan companionship support. Faktor internal datang dari dalam diri subjek sendiri, yaitu adanya motivasi yang kuat dari dalam diri subjek dan kepribadian yang mudah menerima masukan dari orang lain. Terdapat dua hal yang memotivasi subjek, yaitu penolakan atas perlakuan yang subjek terima selama mengalami eksploitasi seksual dan observasi diri serta proses penilaian yang subjek lakukan terhadap dirinya sendiri. Subjek mengalami dampak secara fisik dan psikologis akibat eksploitasi seksual yang dialaminya. Secara fisik dampak yang dialami yaitu penurunan berat badan, bagian kemaluan terasa perih, mual-mual, organ seksual terpapar bakteri, dan keputihan. Dampak psikologis yang dialami yaitu kecemasan, trauma, disfungsi sosial dan depresi. Peneliti menyadari terdapat banyak kekurangan dalam penelitian ini, diantaranya karena informasi yang terbatas terutama tentang latar belakang perjalanan kasus dan keadaan subjek secara keseluruhan saat masih mengalami eksploitasi seksual. Maka dari itu, bagi peneliti selanjutnya disarankan untuk dapat menggali informasi secara lebih mendalam kepada subjek maupun significant person. Selain itu juga dapat ditambah dengan metode observasi khusus, sehingga bisa didapatkan gambaran keadaan subjek secara menyeluruh. Peneliti berharap penelitian ini dapat dikembangkan menjadi penelitian eksperimen sehingga dapat memberikan dampak yang positif secara langsung bagi subjek.

\section{DAFTAR PUSTAKA}

Alwisol. (2012). Psikologi kepribadian, edisi revisi. Malang: UMM Press.

Azwar, S. (2010). Metode penelitian. Yogyakarta: Pustaka Pelajar.

Bandura, A. (1991). Social cognitive theory of self-regulation. Organizational Behavior and Human Decision Processes, 50, 248-287.

BPPM DIY. (2014). Daftar terpilah gender dan anak Daerah Isimewa Yogyakarta tahun 2014. Yogyakarta: BPPM DIY.

Creswell, J.W. (1998). Qualitative inquiry and research design: Choosing among five traditions. California: Sage Publications, Inc.

Dariyo, A. (2011). Psikologi perkembangan anak usia tiga tahun pertama. Bandung: Refika Aditama.

Feist, J., Feist, G.J., \& Roberts, Tomi-Ann (2010). Teori kepribadian: Theories of personality, buku 1. Terjemahan. Jakarta: Salemba Humanika.

Hadi, S. (2004). Metodologi riset. Yogyakarta: Andi Offset.

Hidayah, N. (2007). Sosialisasi nilai-nilai anak sebagai upaya preventif child abuse. Humanitas, 4(2): 95-102.

Hidayat, R., Romas, M.S., Widiastutui, R., Hasyim, N., Saeroni, Hayati, E.N, Qodriati, N. (2009). Wajah kekerasan: analisis atas data kasus kekerasan terhadap perempuan di Rifka Annisa tahun 2000-2006. Yogyakarta: Rifka Annisa Women Crisis Center.

Hutabarat, M., Permana, R., \& Masud, M. (2010). 24 kreasi unik kamar remaja. Bogor: Penebar Swadaya.

Illenia, P., \& Handadari, W. (2011). Pemulihan diri pada korban kekerasan seksual. Ihsan, 13(02): 118-128.

Maslihah, S. (2013). Play therapy dalam identifikasi kasus kekerasan seksual terhadap anak. Jurnal Penelitian Psikologi, 04(01): 21-34.

McCullough, M.E., \& Willoughby, B.L.B. (2009). Religion, self-regulation, and self-control: associations, explanations, and implications. Psychological Bulletin, 135(1): 69-93. 
Moleong, L.J. (2010). Metodologi penelitian kualitatif edisi revisi. Bandung: Remaja Rosdakarya.

Muhadjir , N. (2007). Metodologi penelitian kualitatif. Yogyakarta: Rake Sarasin.

Neal, D.J. \& Carey, K.B. (2005). A follow-up psychometric analysis of the self-regulation questionnaire. Psychol Addict Behav, 19(4): 414-422.

Poerwandari, E.K. (2007). Pendekatan kualitatif untuk penelitian perilaku manusia. Jakarta: LPSP3 Fakultas Psikologi UI

Prastowo, A. (2011). Metode penelitian kualitatif dalam perspektif rancangan penelitian. Jogjakarta: Ar-ruzz Media.

Putra, P.M.S. (2015). Komnas PA: 2015, kekerasan anak tertinggi selama 5 tahun terakhir. https://www.liputan6.com/news/read/2396014/komnas-pa-2015-kekerasan-anaktertinggi-selama-5-tahun-terakhir

Santrock, J.W. (2007). Perkembangan anak, edisi 11, jilid 1. Jakarta: Erlangga.

Sarafino, E.P. \& Smith, T.W. (2012). Health psychology: biopsychosocial interactions (seventh edition). New Jersey: John Willey \& Sons, inc.

Sisca, H., \& Moningka, C. (2008). Resiliensi perempuan dewasa muda yang pernah mengalami kekeraan seksual di masa kanak-kanak. Jurnal Psikologi, 2, 61-69.

Sofian, A. \& Ramlan. (2008). Memerangi pariwisata sex anak: tanya \& jawab. Medan: Restu Printing.

Sulistyaningsih, E., \& Faturochman. (2002). Dampak sosial psikologis perkosaan. Bulletin Psikologil, 10 (1), 9-23. 